IRA-International Journal of Management \& Social Sciences

ISSN 2455-2267; Vol.14, Issue 02 (February, 2019)

Pg. no. 20-39.

Institute of Research Advances

http://research-advances.org/index.php/RAJMSS

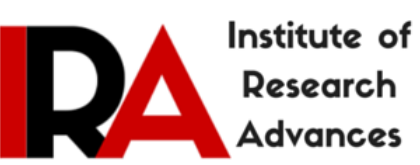

\title{
Gearing Up For Growth \& Sustainability: A Case Study on 'iD Fresh Food'
}

\section{Dr. Shampa Nandi}

Associate Professor, International School of Management Excellence (ISME), Bangalore, India.

Type of Work: Peer Reviewed Case Study.

DOl: http://dx.doi.org/10.21013/jmss.v14.n2.p1

\section{How to cite this paper:}

Nandi, S. (2019). Gearing Up For Growth \& Sustainability: A Case Study on 'iD Fresh Food'. IRAInternational Journal of Management \& Social Sciences (ISSN 2455-2267), 14(2), 20-39. doi:http://dx.doi.org/10.21013/jmss.v14.n2.p1

\section{(C) Institute of Research Advances. \\ (cc) EY-NC}

This work is licensed under a Creative Commons Attribution-Non Commercial 4.0 International License subject to a proper citation to the publication source of the work.

Disclaimer: The scholarly papers as reviewed and published by the Institute of Research Advances (IRA) are the views and opinions of their respective authors and are not the views or opinions of the IRA. The IRA disclaims of any harm or loss caused due to the published content to any party.

Institute of Research Advances is an institutional publisher member of Publishers International Linking Association Inc. (PILA-CrossRef), USA. The institute is an institutional signatory to the Budapest Open Access Initiative, Hungary advocating the open access of scientific and scholarly knowledge. The Institute is a registered content provider under Open Access Initiative Protocol for Metadata Harvesting (OAI-PMH).

The journal is indexed \& included in WorldCat Discovery Service (USA), CrossRef Metadata Search (USA), WorldCat (USA), OCLC (USA), Open J-Gate (India), EZB (Germany) Scilit (Switzerland), Airiti (China), Bielefeld Academic Search Engine (BASE) of Bielefeld University, Germany, PKP Index of Simon Fraser University, Canada. 


\begin{abstract}
The case is all about the journey of an entrepreneur Mr. Musthafa with his venture iD Fresh Foods India Ltd. Back in 2006 with a humble beginning, as a small store selling Idli and Dosa batter at Tippsandra, Bengaluru, iD at 2018, has grown multi-fold, presented in over 21,000 stores, 17 cities and is planning to expand to 30 cities in next few years. A number of accolades in its hat like "Best food marketing idea 2016", "Vocational excellence award 2016", "Best packaging design award 2015" and many other appreciations, "iD Fresh Food" would be a great case study for the B-school students or students of other business management courses and would add value to the marketing or entrepreneurship literature. This case study specially examined the marketing strategies adopted by the company to establish itself in the cluttered RTC (Ready to cook) packaged food sector in an emerging market scenario. The issue of the case is to examine whether the company should diversify or continues its basic philosophy of serving natural preservative free packaged food items and how far the closely-knit management style is going to sustain its market leadership position in future.
\end{abstract}

Keywords: Case Study, Ready to Cook Foods, Entrepreneurship

“iD's philosophy is to enable the homemaker and not to replace her. As a result, all iD products are preservative-free and traditional Indian foods made the natural way, just like 'made-at-home'." (P.C. Musthafa, Founder \& CEO, iD Fresh Food)

With the launch of traditional filter coffee decoction in October 2018 and ready to squeeze and fry Vada batter pack in July 2018, iD Fresh Food was once again all set to continue its pioneer position in Ready to Cook (RTC) packaged food market in India. Foraying in filter coffee business with an expectation of INR 500 million of business in FY2018-19, the sachet of decoction filter coffee was introduced to meet the demand of consumers with coffee connoisseurs. A pouch pack of readymade Vada batter with an umbrella nozzle to create perfectly shape Vada with a hole, an age-old popular south Indian snack was another addition to disrupt the market and became one of the fastest selling items within weeks after launch. Both the offerings were once again aligned with the core philosophy of iD Fresh Food- to serve preservative-free products. iD named after Idly and Dosa, started in Bengaluru, in 2006 as a niche to cater the need for readymade Dosa Idli batter with no big competitors and captured the RTC food market by producing preservative-free quality batter customized to local taste and palate. Increasing sophisticated health awareness, rising demand of hygienically packaged foods as well as Indian's food habit of consuming homemade food had driven the Indian market a perfect place for iD Fresh Food, a company making and selling readymade idly and dosa batter. The company stayed focussed in creating a brand from day one and became a pioneer in this segment very quickly.

With a humble beginning in 2006, iD received a number of accolades (List of awards is added in exhibit 1) and was able to raise an investment of INR 1.5 Billion in February 2017 from Premji Invest and INR 350 Million from Helion Venture in 2014. Once having a fund, the company planned to morph into a multi-product brand, by upgrading the existing system and to expand its business to the international geography such as the US, UK and Singapore to cater the needs for Indian consumers. P C Musthafa, CEO of iD Fresh aspired to be INR 10 Billion Company by the year 2020 as he built a strong brand in a food category with great potential to convert from unorganised to organised packaged foods.

India's RTC food industry witnessed tremendous growth in the last decade. According to the report of British Market Research Company Euro Monitor(April 2017), India would be one of the top five markets for packaged food in the world and is expected to take a third largest market position for packaged food in 2020 (Anurag More, 2018). Though the RTC market was expansive, certain factors could act as a barrier to the growth of the packaged food industry. Due to lack of customers' awareness and low clarity on regulatory mandates on packaged food, trust on packaged food continued to be low in India. Hence, it continued to be difficult to convince Indian customers about the idea of preservative-free packaged food. Further hot and humid climate in India reduced the shelf life of any RTC packaged items. iD's products had a short shelf life as there were no chemicals or preservatives added. The USP of iD for serving preservative free food posed a limitation to the company for product diversification of business. So far, the company was successful in adding products in its Fresh product line, as mentioned at the beginning of the case. Question is how long? The company had limited 
option to add products in the fresh products line, which would go well with its existing business philosophy. Would iD Fresh Food need to diversify from its core principle of serving fresh, natural, no chemical packaged food category or stay with its philosophy of products at the cost of low and slow growth?

\section{PACKAGED FOOD INDUSTRY IN INDIA \& THE MARKET READINESS FOR ID FRESH FOOD}

In India, the packaged food sector emerged as high growth and high-profit sector due to its immense potentials accounting for 32\% of India's total food market and worth $\$ 40$ billion. Food processing industry in India was again one of the largest industries and ranked fifth in terms of production, consumption, export and expected growth and was growing at a Compounded Annual Growth Rate (CAGR) of 20\% (IBEF; June 2017). Post liberalization period, India, as an emerging economy was showing steady double-digit growth in "Ready to Cook" (RTC) food industry especially in tier I and tier II cities. A paradigm shift was observed in living standard and lifestyle among urban and semi-urban Indians after the year 2000. Factors like migration of youth over jobs/education, lack of ready infrastructure for cooking while moving out of their homes, rising dualincome families, diminishing culinary skills, paucity of time led to a market of convenience packaged readymade foods- Ready to Cook (RTC) and Ready To Eat (RTE)packaged food products. Another driving force for penetration of packaged foods was the availability of refrigeration facilities in super store, retail chains, and supermarkets in India as well as the improved supply chain management.

The worth of RTC market was $\$ 233.40$ million (2013) and expected to reach $\$ 754.82$ million by 2022 with a CAGR of $14.59 \%$, according to Market Research Future (MRFR). (Shagun Sachdeva, Aug 2017. Associated Chamber of Commerce and Industry of India (ASSOCHAM) survey (July 2017) stated that 76 per cent of parents in big cities, mostly both working and with children served easy-to-make meals at least 10-12 times in a month in some form or the other (IANS, 2017). In a report published in May 2018, Zurich-based investment bank Credit Suisse predicted that the Indian packaged food market would grow to $\$ 200$ billion over the next decade. Credit Suisse identified three major factors, namely availability, affordability and greater investment for the growth of this sector (Isha Arora, 2018).

Indian RTC market could be segmented based on the geographic region such as north, south, central, west, east and north east market depending on the variety of the cuisine and various food choices. Among all the market, the south region took the most dominant place due to increasing urbanisation and number of migration. Because of the attractiveness of the market, a number of foreign players tried their hands in this industry but very few companies have emerged as major market players. Nestle was the first company which entered the RTC market by introducing instant noodles. Mostly domestic players dominated this market, as they understood the local taste and preference in a much better way than the foreign brands like "Danone", or McCain.RTC food market could be categorized into three segments - snack mix (Dhokla mix, Idli-Dosa mix etc.), dessert mixes (Gulab jamun mix, Kheer mix etc.) and curry making enabler (Gravy mix, Masala mix etc.).

\section{Major players in South Indian Packaged Food Market-}

Some major players in this industry were MTR, Gits, ITC, Bambino, Kohinoor foods, and Nutrela.

MTR- MTR Foods, Bengaluru based company, was one of the top five processed food manufacturers. Started as a restaurant in 1924, MTR has listed as Fortune next 500 companies in 2016. In 2017, it was INR 7 Billion Company with wide ranges of products for all types of meals offering pan Indian customers. In 2013, Norwegian conglomerate Orkla acquired MTR foods. MTR was present all over India but mainly dominated the South Indian market with $72 \%$ market share. MTR served the market with a wide range of products synonymous with quality, taste and convenience. It served both domestic as well as major foreign markets like USA, UK, Australia, New Zealand, Singapore, Malaysia, Japan, Oman and UAE.

Gits- Pioneer brand in the packaged food industry established in 1963. Gits manufactured, sold and exported a wide range of RTE and RTC products. The company was the first company, which introduced instant mixes in India and gained immense popularity in instant RTC market because of its superior quality, intensive distribution network and brilliant marketing strategies. Gits products were widely distributed in India and outside India in more than 40 countries including USA, Australia, Asia, the Middle East and Europe. 
Maiyas- This was another leading brand in South Indian RTE food category. In 1924, Maiyas started MTR, which was synonymous to south Indian traditional foods. In 2007, Maiyas sold MTR to Orkla as a part of a family settlement with a contract that Maiyas would not sell any rivalry products. Targeting especially consumers of the unbranded product who were looking for authentic tastes, Maiyas already had gained popularity in snacks and RTC product categories. In mid of 2018, the company decided to shut down production following a breakdown between founder Mr. Sadanada Maiya and the private equity investor Peepul capital.

ITC- ITC, one of the major conglomerates in India had two categories of RTC foods- Aashirvaad offering a range of daily delights and Kitchen of India offering gourmet food of India. ITC's branded packaged foods business grew tremendously in last few years, with a number of brands in its portfolio in multiple categories of food like staples, spices, biscuits, confectionery, snacks, noodles, pastas, chocolates along with RTC and RTE meals. ITC aimed to outrun two major giants, Nestle and Britannia in the packaged food market.

In pan India market, other major players in the RTC and RTE packaged food industry were Nestle, Haldiram Foods International Pvt Ltd, Himalaya International Ltd, Bambino and Kohinoor Foods Ltd and Bambino Agro Industries Ltd.

iD entered Bengaluru RTC packaged food market at the right time. During 2005-06, though a number of wellknown brands namely Maiyaas, Mavalli Tiffin Room (MTR), GITS food products Pvt Ltd, ITC were available in RTC food sector, no organised player had entered the "Readymade Idli Dosa" batter section in Bengaluru, the birthplace of iD Fresh. A huge market was untapped and some local companies were serving the demand with poor quality products and irregular supply. The real competitor for iD was the homemade batter. Bengaluru, is a busy metropolitan city in South India, had an instant potential demand for readymade batter as it was a regular consumable item in South Indian homes. An inelastic demand was observed from day one in this category.

\section{iD FRESH FOOD'S BIRTH \& INITIAL HURDLES}

Musthafa was bitten up by entrepreneurial bug at the earlier stage of his life (Prasad Usha, 2016). While doing his MBA he used to visit his cousin Nazer's Kirana stores at Thippasandra, Bengaluru during weekends and his free times. He observed that there was a lot of demand for ready-made idli dosa batter in the shop and people were buying irrespective of poor quality and irregular supply. Nazer and Jafar, his cousins suggested him to start a business to sell idli batter. Musthafa invested INR 25,000 to start the batter business. His experience and exposures with MNCs, his cousins' connections with local Malayalee's stores in Bengaluru and the authentic homemade taste of batter helped the business to grow at a quick pace. Initially, iD started with a small amount of batter and distributed as samples to the customers of the known Kirana stores. Once received positive feedback from the consumers the founders gained confidence about starting the idli-dosa batter business.

The journey of iD Fresh Food was not a cakewalk at the beginning. All the founders were from Kerala where idli was not as common as appam. Finding the correct recipe was a challenge. They could sell appam batter but that required a good amount of fermentation, which did not gel well with iD's USP of producing preservativefree food. Again, Bengaluru had a limited market for appams. In 2005, after hiring 60 square feet of space in Indira Nagar, Bengaluru, the founders took almost six months and 3 tonnes of rice to get a perfect idli dosa batter mix.

Hurdles faced by the founders to start iD Fresh Food -

- Convince people about the concept of fresh, natural and preservatives free RTC packaged food. Preservatives were added in most of the available packaged foods, so convincing consumers, retailers and even employees about the idea of preservative-free packaged products was difficult. It took some time to educate and convince people.

- Another challenge was to estimate accurate market demand for iD products. Since iD catered the fresh food segment with low shelf life, the wastage cost was high.

- The third challenge was that none of the founder members had any background in the food industry. They made many mistakes at the initial level. 
- They also faced a challenge to remain focussed on ethical values and delivery of consistent quality. So initial operational costs were high.

- Cash flow was another challenge as none of the founders was from a wealthy business background. (Himnshu Kakkar (2017),

In spite of the challenges faced by Musthafa, there was profit in the business from day one (Refer to Table 2 in Exhibit). Therefore, he was never in dilemma, whether to run the business or not. By 2006, the company was able to sell to nearly 200 grocery stores in Bengaluru. Seeing the continuous growth of the business Musthafa had to make a decision to put a shape to the business, rather than just being an investor, he joined the business full time. With proper organisational structure and with the intention to run it professionally, the company started operating formally. In the beginning, the company started as "Best Food Pvt limited'; later to avoid a copyright issue, the company changed its name to "iD Fresh Food Private Limited" (Source: Marketing Dept., iD Fresh Food).

\section{THE ENTREPRENEUR: P.C MUSTHAFA, FOUNDER OF ID FRESH FOOD}

Musthafa was born at Chennalode, a remote village in Wayanad district of Kerala in a poor family. His father was a daily wager and the family lived on the meagre earnings of his father. As a child, he used to help his father in his labour jobs after school and during holidays. He was an average student and failed in sixth grade. His father wanted him to join in his work for full time and discontinue his study but his Math teacher Mr. Mathew had convinced his father to pursue his education further.Mr. Mathew took special care for his studies and Musthafa continued to excel in studies. After completing his engineering in 1995, he was placed in a startup company of Bengaluru. For the company assignment, he went to Ireland and worked there for one and half year. He found it difficult to adjust to the food habits of Ireland, and decided to shift to "Malayalee's own country- Dubai”. In 2003, after seven years of stay in Dubai working with Citi Bank, he returned to Bengaluru, India. He returned, as he wanted to spend more time with his parents, to pursue higher education and above all do something for the society. Returning to Bengaluru, he joined IIM, Bengaluru and did Executive MBA programme (Jubin Mehta, 2015) (Prasad Usha, 2016).

\section{BRAND BUILDING STRATEGIES OF iD}

iD was never in hurry to penetrate the crowded market and never weaved from its basic philosophy. To create a brand for an unbranded commodity, rather than selling to every mom and pop stores, it emphasized on product quality, on own distribution models (trucks \& salesmen) and sold at selected stores. In 2017, iD created its presence in 17 cities viz. Bengaluru, Chennai, Mumbai, Pune, Cochin, Coimbatore, Vijayawada, Guntur, Rajahmundry, Visakhapatnam, Vizag, Mysore, Mangalore, Sharjah, Dubai, Abu Dhabi \& Ajman. In an interview with Brand Capital (Mar 22, 2018) Musthafashared the success mantras on how iD created a niche-

- $\quad$ Build a brand for your product.

- No credit was given to the retailers and the company was tightly managed its finance from day one.

- Consistent quality of products, no compromisation on that end.

- Any company should concentrate to make a profit from day one.

- One size does not fit all. Musthafa stated that every market had unique features.

- Innovation should be a continuous process.

- The company should focus to add value to the investors and should identify the right investors.

- The customer was queen-iD believed in having a strong connection with customers and a company should understand what role the products or services of the company play in a customer life. (Brand Story by Brand Capital, 2018)

iD continued to sustain its business and maintained its growth with the following marketing strategies:

\section{Target customers}

The primary target for iD fresh food were women, both homemakers as well as working women of age group 26 + years, in the upper and upper middle class of the society (Source: Marketing Dept, iD Fresh Food). A large number of men also found iD products very handy and tasty and preferred iD's "Ready to eat Parotas". 


\section{Product, Packaging and Positioning}

The preparation of iD food products followed the ultra-hygienic process in HACCP (Hazard analysis critical control point) compliant factories. Product ranges include a wide variety of products starting from Idli, Dosa batter, Udipi style Idli batter, Paneer, Curd, and ready to heat parotas like Malabar Parota, Whole wheat Parotas, Parota for Juniors, and Mini Parotas. After introducing the "Vada Batter" in handy pouches in 2018, the company filed a patent for its innovative packaging. The product was a great hit in the market and it helped iD to penetrate more. In the health food segment, iD also introduced "Ragi Batter" and batter made of Oats and other millets. Though a wide array of products in its SKUs(Stock keeping units) to cater to various needs of customers, lion share of the company's revenue came from idli dosa batter (55\%) while parota contributed (30\%), chapatti (7\%) and the rest from dairy and other products(Source: Marketing Dept, iD Fresh Food). After receiving feedback from customers, iD had introduced a "transformed pouch" pack for dosa, idly batter with the boat-shaped bottom, which would work as a tub for storage for left out content.

\section{Price}

iD started with value-based pricing and targeted premium customers. Price of iD products was higher than competitors' products. Musthafa stated, "If the products are worth, add value to the customers, the price is always right".Price for one Kilogram idli dosa batter was Rs70 in 2017 where as competitive brands in Bengaluru, like Hallimane was sold INR55 for $1 \mathrm{~kg}$, Asal for INR 65/kg, Chef's choice for INR 60/kg. Post demonetization period, iD offered some Paytm cash back offers to encourage the non-cash payment transaction. It also offered, "Combo pack" and "Family pack" to cater to diverse consumers" demands. In July 2017, with the introduction of GST (Goods \& Services Tax) by Central Government in India, iDwas running a bit short in generating revenue. The rate of GST on idli and dosa batter reduced from $12 \%$ to $5 \%$ and the traders ceased to stock the products, as they found difficult to sell the products at old rates.

\section{Place/ Distribution}

The company directly distributed the products and was extremely choosy in selecting the retailers onboard, as the products needed to be refrigerated properly. The products were sold only through those retailers who did not switch off their chillers at night. In 2017, the number of such retailers was only 6000 out of total 65,000 retailers in Bengaluru city. To deliver fresh products the company had manufacturing unit at Bengaluru (Hoskote), Chennai, Hyderabad, Mumbai and Ajman in the gulf area. The share of revenue from different market found out to be $40 \%$ from Bengaluru, Dubai 20\%, Mumbai 12\%, Hyderabad 12\% whereas other cities around 16\% (Source: Marketing Dept., iD Fresh Food). For online selling the company collaborated with well-known online retailers Big Basket and Grofers(Team PDD (2016). In the B2B business, the company appointed dedicated sales force that catered to hotels such as Taj, Lemon Tree and Marriot, restaurants such as Adiga's and Empire outlets and well-known caterers and airline kitchens such as Oberoi flight kitchen and Sky gourmet.

\section{Use of "State of the art Technologies"}

For accurate estimation of demand, sales team usedSAP-based software "BIZOM' which worked on real-time data. This mobile app helped the company to keep track of the sales pattern in each store and to maintain zero inventory model- almost $90 \%$ of the products were sold on the same day. Musthafawasalways keen for adopting latest technologies to improve operational efficiencies and during 2015-18, the company spent around INR 20 Million on technology, which included machinery and other software like "Geofencing" (Himanshu Kakkar, 2017). Geofencing is a software using GPS technologies, which helped iD to track its supplies, ensured that supplies reach on time and finally controlled the wastage.

\section{Promotion \& Marketing Communication}

According to Musthafa, word of mouth worked wonders for iD. He strongly believed that if the product was packaged right, and customers were serviced properly, half the marketing was done. This could be the cheapest form of marketing or branding. (Himanshu Kakkar, 2017).iD used a 360-degree branding and marketing approach through various communications like Above the line advertising (ATL), Below the line advertising (BTL), digital marketing, social media marketing and building public relation. ATL was mainly used to enhance 
brand awareness, brand recall and visibility by using strategies like bus shelter campaign, gantry advertising, and attractive digital screen display at airport and metro stations, television advertising, especially in regional channels, newspaper advertisement, radio advertisement. The company relied heavily on below the line promotional methods because of the nature of products sold. BTL helped the company to enhance persuasion of the purchase decision. For BTL promotion, iD used displays and hoarding at the point of sale, in a retail store, and YouTube viral. Occasionally it did price promotion though, the company was cautious of not diluting its premium product image. Musthafa took special care for creating public relation by attending press interviews, tv releases, trade shows, conferences, talk shows etc. To create social awareness, iD launched a digital campaign with Army veterans, and campaigned in the month of August, during Independence Day celebration of India. iD even experimented with disruptive marketing activities like "Trust shop" at limited places where customers had the option to take products from vending machines and pay later if satisfied. This venture was not successful. Another recent ad campaign launched by iD was "MYN-Meet your Neighbour" which was all about bringing communities together by inviting neighbours to join a home-cooked meal. (Source: Marketing Dept., iD Fresh Food).

\section{THE JOURNEY AHEAD AND THE CHALLENGES ALONG THE WAY}

Growing demand for "packaged food', both in the categories of RTC and RTE were observed for the past few years and this trend would continue even in the future. Packaged food market was mainly concentrated in Urban India (around 80\%). However, almost 65\% of Indian Population lived in Rural India(Anurag More, 2018). With the improvement of infrastructure and an increase in wages, the rural market was coming up as a promising market. iD Fresh food was ambitious and confident to establish itself as an INR 10 Billion company in this segment by 2020(Deepti Govind, 2018). Rahul Garg, partner of Premji invest acclaimed, "There is a billion dollar opportunity in the RTC segment, where iD has achieved the market leader position due to its first mover advantage" (Kashyap S., 2017).

With raised funds from Premji Invest, and Helion Venture, company planned to upgrade the existing system, invest more in Research \&Development and consider expansion to widen its reach. Company'sgrowth plan included starting three modern plants in Bengaluru, Mumbai and Dubai, and close down old plants in Mumbai and Dubai. The company would like to increase its production capacity by seven times with new production set up. iD's expansion plan included market penetration, product development and geographic expansion. Existing RTC market across Chennai, Bengaluru, Mumbai and Hyderabad was on a steep rise because of large migrated professional and iD wanted to be a household name for the daily meal. iD planned to enter into Delhi and Ahmedabad market after its success in South Indian market. It also planned to expand its business in ten Middle East cities, specifically Muscat and Kuwait, US, UK and Singapore. Test launching started for all these overseas market and the company initiated scrutinizing all possible options to enter foreign markets.

iD knew that initial success could be slowed down by stiff competitions from forthcoming local "me too" types of substitute products. Again, Western breakfast and snacks were gaining popularity due to globalisation and lifestyle changes in the urban area. Challenges even lied on maintaining global standards of food safety, creating awareness, infrastructure backup as well as effective distribution networks in these new geographies. What would be the best way to add more products to the existing product line? Should it diversify shifting from its core philosophy of serving preservative free natural packaged food? The company reached a great height within a short span. Is it because of Musthafa's innovative and professional management style? Should the company decentralise its existing close-knit management style to achieve rigorous expansion and achieve projected growth? Would it be able to meet the customers' expectation in overseas countries and maintain a global standard?

\section{REFERENCES}

[1]. Anurag More (2018), "India to be world's 3rd-biggest packaged food market", FnB News.com. Available at:http://www.fnbnews.com/Interview/india-to-be-worlds-3rdbiggest-packaged-food-market-43250

[2]. Brand Story by Brand Capital (2018), "ID Fresh Products + Brand Capital = A Recipe for Success". Times of India (online).Available at: https://timesofindia.indiatimes.com/business/india-business/id-fresh-products-brand-capitala-recipe-for-success/articleshow/63410862.cms 
[3]. Deepti Govind (2018), “iD Fresh Food to expand capacity, launch new products”, Livemint.com. Available at: http://www.livemint.com/Industry/0Y3rjCxx6ICocR5Zsk6BK/iD-Fresh-Food-expand-capacity-launch-newproducts.html

[4]. Himanshu Kakkar (2017), “ iD's Magic”, Outlook Business, The power of I 2017, [online], Available at: https://www.outlookbusiness.com/specials/the-power-of-i_2017/ids-magic-3617

[5]. IANS(2017), "Indian Packaged Food Market To Be Worth \$50 Billion By 2017”, NDTV Food. Available at :https://food.ndtv.com/food-drinks/packaged-food-market-to-be-worth-50-bn-by-2017-1254654

[6]. Isha Arora(2018), Why India’s Packaged Food Market Will Jump To \$200 Billion In A Decade, Bloomberg. Available at : https://www.bloombergquint.com/business/2018/05/02/why-indias-packaged-food-market-willjump-to-200-billion-in-a-decade

[7]. Jubin Mehta (2015), "How iD Fresh manages to supply packaged batter for a millions of Idlies every day", Your Story, 2 November, 2015.Available at : https://yourstory.com/2015/11/id-fresh/

[8]. Kashyap Sindhu (2017), “iD Fresh Food raises \$25M from Premji Invest, aims for Rs 250cr revenue in the coming year”, Your story.com, Available at : https://yourstory.com/2017/03/id-fresh-food-premji-invest/

[9]. Prasad Usha (2016), "He got batter and batter daily and today helms a Rs 100 crore turnover company", The Weekend Leader. Available at http://www.theweekendleader.com/Success/2555/getting-batter-daily.html

[10]. ShagunSachdeva, Aug 2017, India's RTC food mkt estimated to reach $\$ 382.06$ million by end of 2017, Fnbnews.com

[11].Team PDD (2016), "How iD Fresh Foods strong brand philosophy helped it become a Rs 100 crore company and a strong household name in 10 years", Project Deep Drive 2 April, 2016

[12].www.ibef.org (available at https://www.ibef.org/industry/indian-food-industry.aspx)

[13].www.idfreshfood.com

[14].www.mtrfoods.com

[15].www.gitsfood.com

[16].www.maiyas.in

[17].www.itcportal.com 


\section{EXHIBITS:}

List of awards received by iD Fresh Food

- "Best Food Marketing Idea - 2016"

- "Vocational Excellence Award 2016"

- "India's Small Giant Season II 2016"

- "Best Packaging Design 2015"

- "Entrepreneur of the year in manufacturing business; FMCG-2015"

- "Big Bang Award-Best packaging design 2014"

- "Indian Achiever Award 2012"

(Source: Marketing Dept, iD Fresh Food)

Table 1

Financial Details of iD Fresh Food: (in INR Millions)

\begin{tabular}{|l|l|l|l|r|r|}
\hline Description & FY 2015-16 & FY 2014-15 & FY 2013-14 & FY 2012-13 & FY 2011-12 \\
\hline Income & 806.808 & 552.387 & 355.003 & 253.90 & 171.40 \\
\hline Purchases & 436.102 & 327.737 & 179.336 & 134.50 & 85.80 \\
\hline Salary expenses & 181.506 & 111.635 & 468.944 & 14.00 & 26.90 \\
\hline Electricity expenses & 9.33 & 6.09 & 3.45 & 2.80 & 1.30 \\
\hline Depreciation & 32.37 & 17.36 & 3.94 & 3.90 & 2.90 \\
\hline Loans & 0 & 0 & 24.84 & 32.60 & 12.80 \\
\hline Sundry creditors & 40.02 & 34.85 & 18.41 & 2.30 & 5.70 \\
\hline Fixed assets & 65.57 & 79.64 & 24.07 & 21.70 & 22.10 \\
\hline Loans and advances & 60.73 & 33.74 & 30.17 & 12.40 & 11.70 \\
\hline
\end{tabular}

(Source: Marketing Dept., iD Fresh Food)

Table 2: Organisation Structure of iD Fresh Food

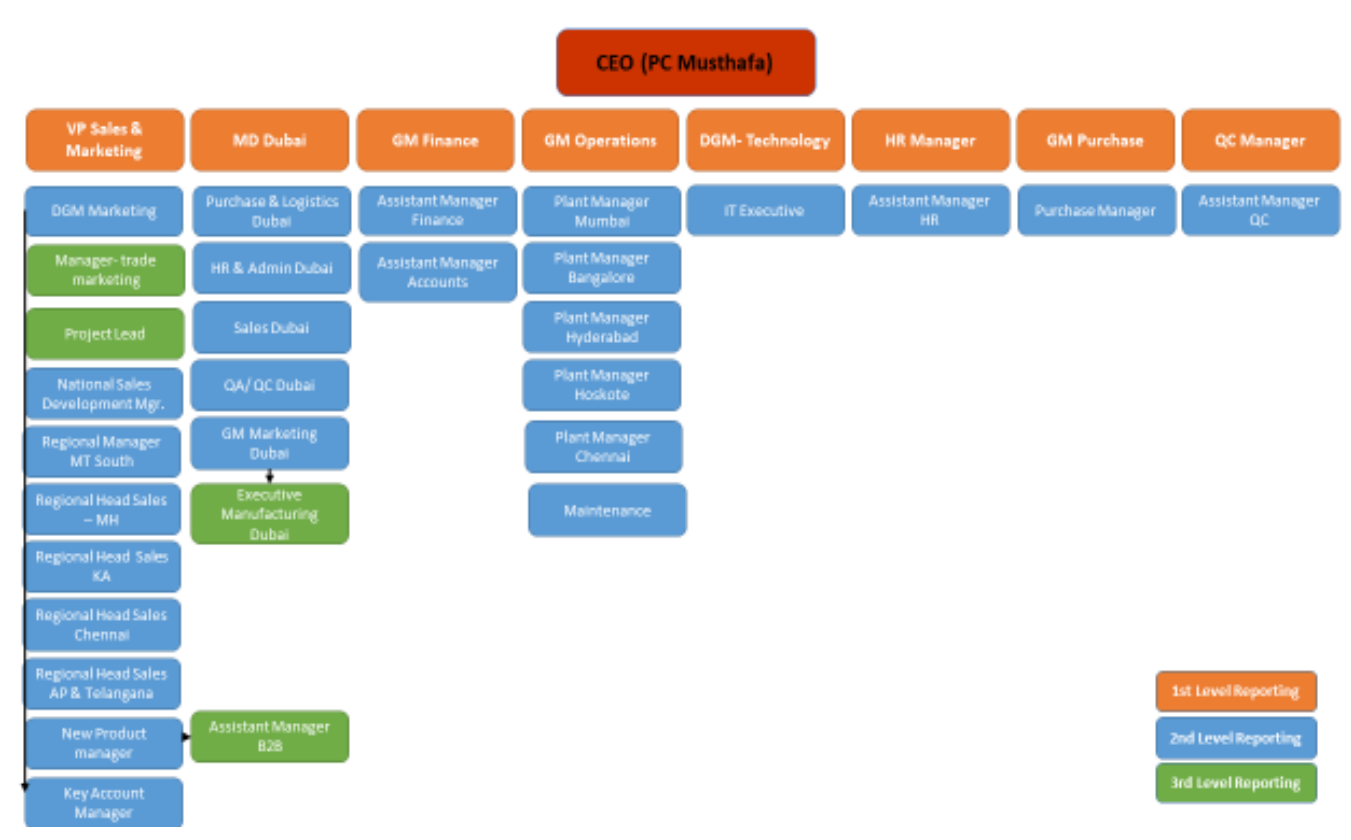

(Source: Marketing Dept., iD Fresh Food) 
Table 3

\begin{tabular}{|c|c|}
\hline \multicolumn{2}{|l|}{ Glossary of Terms } \\
\hline Terms & Meaning \\
\hline $\begin{array}{l}\text { Above the Line } \\
\text { promotion and Below } \\
\text { the Line promotion }\end{array}$ & $\begin{array}{l}\text { Before going to differentiate between "Above the line or ATL" and "Below the Line } \\
\text { or BTL" promotion, it needs to be clarified, what does the word line mean here. In } \\
\text { 1954, when Proctor and Gamble started paying at different rates to different media, } \\
\text { the concept came into existence as mentioned by Michel John Baker in "Marketing } \\
\text { Book". ATL is a promotional strategy focuses on a larger audience and mass media } \\
\text { like advertising through TV/Radio, print or internet are used. They are not specific to } \\
\text { individual customers. They are expensive and companies should use BTL promotion } \\
\text { when the budget is an issue. } \\
\text { Below the Line advertising is specific, one to one promotional strategy where } \\
\text { advertising is done through pamphlets, handbill, stickers, roadside banners, brochure } \\
\text { placed at the store or near the point of sale, a demo of goods at malls, events, and } \\
\text { SMS. For the rural market, where mass media fails o reach, BTL can be used } \\
\text { judiciously. BTL focuses more on the targeted audience. Social media Marketing, } \\
\text { Paid searches, Content marketing are some latest addition in BTL promotion, which is } \\
\text { very effective to any company. } \\
\text { In a broad view, ATL works more on creating awareness, and interest while BTL } \\
\text { works best in persuasion or action part of the purchase. } \\
\text { For measuring the effectiveness of ATL the parameters like a reach, frequency and } \\
\text { impact are used where as BTL can be measured through website visits, click through } \\
\text { rates; cost per click, social media likes. Here Google analytics, Social analytics, goal } \\
\text { tracking are very useful. }\end{array}$ \\
\hline Appam & $\begin{array}{l}\text { Appam is the type of savoury rice cakes, popular food of Kerala, a state of South } \\
\text { India. }\end{array}$ \\
\hline Chapati & Type of Indian flat bread. \\
\hline Dosa & $\begin{array}{l}\text { Another Indian popular breakfast or snack made from fermented batter. It is a type of } \\
\text { pancake which is similar to a crape. }\end{array}$ \\
\hline Dip Stick Survey & $\begin{array}{l}\text { This is a survey with open-ended questions where any consumer can open up his/her } \\
\text { mind. It is a type of exploratory research. The dipstick is used as any stick is dipped } \\
\text { into a container to understand the depth of a liquid. Similarly, Dipstick survey helps } \\
\text { to understand any problem in depth. }\end{array}$ \\
\hline Idli & $\begin{array}{l}\text { Idli is popular Indian breakfast foods, type of savoury rice cakes, mostly used in } \\
\text { South India. Idli is made by steaming a batter consisting of fermented black grams } \\
\text { and rice. }\end{array}$ \\
\hline Idli-Dosa Batter & $\begin{array}{l}\text { The batter is a mixture of rice and black grams that have been soaked in water, } \\
\text { ground finely and fermented for some times. Idli, Dosa and some more popular } \\
\text { breakfast and snacks are made from batter. }\end{array}$ \\
\hline Kirana Stores & Mom and Pop store- type of retail store. \\
\hline Malayalee & People originated from the state of Kerala. \\
\hline Niche Marketing & $\begin{array}{l}\text { It is targeted marketing specially focussed on a particular segment catering very } \\
\text { specific need. }\end{array}$ \\
\hline Paneer & Type of Cottage Cheese used in the Indian subcontinent \\
\hline Parota & $\begin{array}{l}\text { A flatbread made from flour that originated in the Indian subcontinent and a very } \\
\text { popular food across India. }\end{array}$ \\
\hline $\begin{array}{l}\text { 360-degree branding } \\
\text { approach }\end{array}$ & $\begin{array}{l}\text { A holistic approach of Marketing that includes brand identity, all marketing activities } \\
\text { and communication to present the brand at all customer contact points. Example- } \\
\text { Store Display, Roadside banner, Advertisement through various media. }\end{array}$ \\
\hline Vada & $\begin{array}{l}\text { Another very popular south India breakfast and snack item, made from Black Gram } \\
\text { batter. }\end{array}$ \\
\hline
\end{tabular}

(Source: Secondary data available in the book, inter 


\section{Addendum}

\section{TEACHING NOTES}

\section{CASE SYNOPSIS}

The case is all about the journey of an entrepreneur Mr. Musthafa with his venture iD Fresh Foods India Ltd. Back in 2006 with a humble beginning, as a small store selling Idli and Dosa batter at Tippsandra, Bengaluru, iD at 2018, has grown multi-fold, presented in over 21,000 stores, 17 cities and is planning to expand to 30 cities in next few years. A number of accolades in its hat like "Best food marketing idea 2016", "Vocational excellence award 2016", "Best packaging design award 2015" and many other appreciations, "iD Fresh Food" would be a great case study for the B-school students or students of other business management courses and would add value to the marketing or entrepreneurship literature. This case study specially examined the marketing strategies adopted by the company to establish itself in the cluttered RTC (Ready to cook) packaged food sector in an emerging market scenario. The issue of the case is to examine whether the company should diversify or continues its basic philosophy of serving natural preservative free packaged food items and how far the closely-knit management style is going to sustain its market leadership position in future.

\section{COURSE POSITIONING}

The case is suitable for a business management programme either at UG and PG level. It is recommended for teaching "Principle of Marketing Management" or "Entrepreneurship Development" courses and it gives students a chance to explore various marketing strategies, managerial decision making or entrepreneurial development in an emerging market. Students who have no prior knowledge on marketing area would be benefitted by this case to understand various marketing concepts applicable in any business and help them to examines the thought-provoking factors that have contributed to the victory of "iD Fresh Food" in gaining a remarkable success. Besides, it may be useful in short duration programme on Entrepreneurial Development as the case clearly depicted a journey or a road map of an entrepreneur and can act as a motivator for the budding entrepreneurs.

\section{LEARNING OBJECTIVES}

After completing the discussion on this case, the students will be able to

1. Summarise fundamental marketing concepts and 4 Ps of marketing used by the company.

2. Identify the challenges faced by a local company in sustaining its market.

3. Examine how to create a niche with the help of USP (Unique Selling Proposition) and to create a brand in a commodity market.

4. Differentiate the applicability of "Above the line and below the line promotional strategies" in a business context.

5. Develop the most appropriate marketing strategies needs to be adopted in an extremely competitive market for expansion.

\section{TEACHING PLAN AND ANALYSIS}

The case can be discussed in a session of 90 Minutes. Students should be able to discuss the case in the classroom session with a presentation or interaction style. The flow of classroom teaching should be as follows:

\begin{tabular}{|l|l|l|l|l|}
\hline $\begin{array}{l}\text { Timings in } \\
\text { order }\end{array}$ & Activities & Los & What the instructor does & What students do \\
\hline $\begin{array}{l}\text { First } \\
0-5 \text { mins }\end{array}$ & $\begin{array}{l}\text { To facilitate group working, } \\
\text { students should sit in groups. }\end{array}$ & & $\begin{array}{l}\text { Instruct students to form } \\
\text { groups of 5 in such a way } \\
\text { that each group consists of } \\
\text { students with a range of } \\
\text { abilities. }\end{array}$ & Form groups. \\
\hline $\begin{array}{l}\text { Next } \\
5-15 \text { mins }\end{array}$ & Instructor-led the discussion. & LO1 & $\begin{array}{l}\text { Introduce the notions of basic } \\
\text { marketing concepts and 4Ps }\end{array}$ & $\begin{array}{l}\text { Listening \& Note- } \\
\text { taking }\end{array}$ \\
\hline
\end{tabular}




\begin{tabular}{|c|c|c|c|c|}
\hline & & & $\begin{array}{l}\text { in marketing. The instructor } \\
\text { can explain each concept } \\
\text { with the example discussed } \\
\text { in the case. }\end{array}$ & \\
\hline $\begin{array}{l}\text { Next } \\
15-25 \text { mins }\end{array}$ & $\begin{array}{l}\text { An overview of the case. } \\
* * \text { Students should be asked } \\
\text { to read the case prior to attend } \\
\text { the class. }\end{array}$ & $\begin{array}{l}\text { LO1 } \\
\text { LO2 }\end{array}$ & $\begin{array}{l}\text { Prompt students to get } \\
\text { familiarise with the } \\
\text { situations, main characters, } \\
\text { the context of the country } \\
\text { discussed in the case. }\end{array}$ & $\begin{array}{l}\text { Students should jot } \\
\text { down all bullet } \\
\text { points discussed in } \\
\text { the case. }\end{array}$ \\
\hline $\begin{array}{l}\text { Next } \\
25-40 \text { mins }\end{array}$ & $\begin{array}{l}\text { Students should be asked to } \\
\text { identify and discuss the } \\
\text { meaning of the specific } \\
\text { marketing terms discussed in } \\
\text { the case. For example- USP, } \\
\text { Niche Strategy, 4Ps, } \\
\text { Targeting, Positioning, } \\
\text { Branding, Marketing } \\
\text { Communication, Dipstick } \\
\text { Survey, ATL and BTL etc. }\end{array}$ & $\begin{array}{l}\text { LO1, } \\
\text { LO3, } \\
\text { LO4 }\end{array}$ & $\begin{array}{l}\text { Interact with students and } \\
\text { prompting them to consider } \\
\text { elements of Marketing. Use } \\
\text { leading questions to help } \\
\text { students to understand all } \\
\text { concepts. }\end{array}$ & $\begin{array}{l}\text { Discussing and } \\
\text { taking notes. }\end{array}$ \\
\hline $\begin{array}{l}\text { Next } 40-55 \\
\text { mins }\end{array}$ & $\begin{array}{l}\text { Discuss Assignment questions } \\
1,2,3 \text { and } 4 .\end{array}$ & $\begin{array}{l}\text { LO1, } \\
\text { LO2, } \\
\text { LO3 } \\
\text { LO5 }\end{array}$ & $\begin{array}{l}\text { Interact with students and } \\
\text { instruct them to explain the } \\
\text { challenges and opportunities } \\
\text { available in the RTC } \\
\text { packaged food market. Also, } \\
\text { help students to extrapolate } \\
\text { the answers from the case }\end{array}$ & $\begin{array}{l}\text { Students should } \\
\text { discuss and write } \\
\text { the key players in } \\
\text { the packaged food } \\
\text { sector and how iD } \\
\text { has entered the } \\
\text { market. Prepare the } \\
\text { SWOT of iD. }\end{array}$ \\
\hline $\begin{array}{l}\text { Next } \\
55-75 \text { mins }\end{array}$ & $\begin{array}{l}\text { Students answering question } \\
5,6,7\end{array}$ & $\begin{array}{l}\text { LO2, } \\
\text { LO3, } \\
\text { LO5 }\end{array}$ & $\begin{array}{l}\text { All three questions } \\
\text { controversial in nature and } \\
\text { there can be more than one } \\
\text { answer. Students should } \\
\text { discuss alternate answers } \\
\text { highlighting their thoughts } \\
\text { about the case study. }\end{array}$ & \\
\hline $\begin{array}{ll}\text { Last } & 75-90 \\
\text { mins }\end{array}$ & $\begin{array}{lll}\text { Presentation } & \& & \text { Plenary } \\
\text { Session } & & \end{array}$ & & $\begin{array}{l}\text { Instructor prompts each } \\
\text { group to present their } \\
\text { feedback to the rest of the } \\
\text { class along with the main } \\
\text { points. } \\
\text { Recap the main points }\end{array}$ & $\begin{array}{l}\text { Students presenting } \\
\text { and answering. }\end{array}$ \\
\hline
\end{tabular}

\section{DATA COLLECTION METHODS}

The case design adopted for this study is mostly descriptive in nature. The case is developed with prior consent from the company "iD Fresh Food". Data was collected through regular and direct interaction with the company representative from Marketing Department assigned by the protagonist. Secondary data about the company was collected through the company's website, written materials and articles published in different newspapers and online publications. Though secondary data were used, the emphasis was given to views, opinions and quotes of the protagonist published in various secondary sources. Hardly the views of the authors were given importance in the case. Secondary data was used as it was difficult and time-consuming to meet the protagonist many times. 


\title{
ASSIGNMENT QUESTIONS WITH ANSWERS
}

\section{What are the challenges the company might face in future?}

Answer:

Some students might point out and discuss the challenges mentioned at the beginning and the end of the case. There might be a number of challenges that iD needs to have a close look.

- $\quad$ Since, RTC packaged food segment is lucrative and growing in India, many new and established companies are attracted toward this segment. iD's initial success could be slowed down by stiff competitions from forthcoming local "me too" types of substitute products who may sell products at a lower price.

- In India, due to lack of consumer awareness and low trust on legal compliance convincing customers about preservative free packaged items is difficult. Limited shelf lives of iD products and India's hot, humid climate may pose challenges to the company to add products in its existing product line.

- A current trend of preferring western breakfast and snacks than traditional Indian food items is observed among urban Indians, especially among kids. Globalisation, global exposure and lifestyle changes are mainly causing the shift in food habits in urban India. So far, iD's products are concentrated in Authentic South Indian delicacies like idli, dosa etc.

- Another challenge to the company lies in its existing philosophy of serving natural, preservative-free foods. Due to the USP, iD has limited option to add products in the fresh products line.

- Since the company is planning to enter the overseas market, challenges even lied on maintaining global standards of food safety, creating awareness, infrastructure backup as well as effective distribution networks in those new geographies.

- Close-knit family members currently manage the company with control residing in the hands of a few family members. Managing and decision-making could be an issue in future once the company will achieve projected growth.

\section{Discuss 4Ps of Marketing used by the company and explain why it is important}

to stay in touch with customers?

\begin{abstract}
Answer:
iD was never in hurry to penetrate the crowded market but was always consistent to its basic philosophy, to create a brand out of an unbranded commodity. iD's growth path was absolutely promising and envious to many prominent FMCG companies in India. Targeting the urban women of upper and upper middle class, iD achieved the market leader position with innovative packaging, unique product features, and a distinct delivery system within a very short span of time.
\end{abstract}

4Ps of Marketing followed by the company are as follows:

Product: Starting with readymade idli dosa batter, iD offered a wide array of products like Udipi style idli batter, Paneer, Curd, and ready to heat parotas (Indian bread) like Malabar Parota, Whole wheat Parotas, Parota for juniors, and Mini Parotas. In early 2018, iD came up with its innovation "Vada Batter" in handy pouches that allow consumers to squeeze vadas directly into hot oil by eliminating the messy process. Again in October 2018 the company launched sachet of decoction filter coffee to meet the demand of consumers with coffee connoisseurs All products were naturally prepared with quality ingredients, following authentic recipes and ultra-hygienic process in HACCP (Hazard analysis critical control point). Its super food portfolio range included "Ragi Batter" and is planning to introduce batter made from other healthy grains like millets and oats etc. 
Price: Pricing strategy adopted by the company was value-based pricing and Musthafa strongly believed that "if the products were worth, the price was always right." Targeting premium customers, products of iD were slightly high priced than the available competitors' products. iD encouraged the non-cash payment mode and offered some Paytm cashback offers. It also offered various value packs like combo pack, family pack etc. to cater to the needs of customers.

Place: Rather than selling to every mom and pop stores, iD emphasized on own distribution models (trucks \&sales representatives) and sold at selected stores. In 2017, iD created its presence in 17 cities including major cities in India and Sharjah, Dubai, Abu Dhabi \& Ajman of Middle East. It was extremely choosy in selecting the retailers on board, as the products needed to be refrigerated properly. To deliver fresh products the company had manufacturing unit at Bengaluru (Hoskote), Chennai, Hyderabad, Mumbai and Ajman in the gulf area. For online distribution, it collaborated with Big Basket and Grofers and appointed dedicated sales force to deal with major hotels, important caterers and airline kitchens.

Promotions: Musthafa said, word of mouth worked wonders for iD. According to him, if the product was packaged right, and customers were serviced properly, half the marketing was done. This could be the cheapest form of marketing or branding. iD used a 360-degree branding and marketing approach which was centred on consumers through various communications like ATL (above the line advertising), BTL (below the line advertising), digital marketing, social media marketing and building public relation. For ATL, iD advertised through bus shelter campaign, gantry advertising, and digital screen displays at airport and metro stations, television advertisements in regional channels, newspaper and radio advertisement. The company relied heavily on below the line promotional methods and used displays and hoarding at a retail store, and YouTube viral. The company did price promotion occasionally. Musthafa took special care for creating public relation by attending press interviews, tv releases, trade shows, conferences, talk shows etc. iD even experimented with disruptive marketing activities like "Trust shop" at limited places where the products were sold through vending machines. Customers had the option of taking it free and pay back if satisfied. The very recent ad campaign launched by iD was "MYN-Meet your Neighbour" which was all about bringing communities together by inviting neighbours to join a home-cooked meal. (Source: Marketing Dept., iD Fresh Food).

\section{Why is it important to stay in touch with customers?}

\section{Answer:}

From day one, iD emphasized on Customer retention and regularly conducted "Dipstick survey" to analyse the strengths and weakness of the company. Its business worked on integrity and the products were known for its consistently high quality and authentic taste. The company had a consumer redressal mechanism where every consumer was attended by the marketing team. There was an option available in the iD website to get connected directly the CEO of the company to discuss any issue. "Customer was queen"- stated by Mustafa and a company should understand what role the products or services of the company play in a customer life.

Theory: 4Ps of Marketing(McCarthy, Perreault, 2002).

\section{What are the major players in Ready to cook segment India?}

\section{Answer:}

According to a report published by British Market Research Company Euro Monitor (April 2017), India would be one of the top five markets for packaged food in the world and India is expected to take the third largest market for packaged food in 2020. Major players in South India in the RTC packaged food segment are MTR, Maiyas, GITs, ITC. Other dominant players in India in RTC and RTE packaged food categories are- Haldiram Foods International Pvt Ltd, Himalaya International Ltd, Bambino and Kohinoor Foods Ltd and Bambino Agro Industries Ltd.

MTR- Started as a restaurant in 1924, MTR has listed as Fortune next 500 companies in 2016. In 2017, it was INR 7 Billion Company with wide ranges of products for all types of meals offering pan Indian customers. 
GITs- Pioneer brand in the packaged food industry established in 1963. GITs manufactured, sold and exported a wide range of RTE and RTC products to USA, Australia, Asia, the Middle East and Europe.

Maiyas- This was another leading brand in South Indian RTE food category. In 1924, Maiyas started MTR, which was synonymous to south Indian traditional foods. In 2007, Maiyas sold MTR to Orkla as a part of a family settlement with a contract that Maiyas would not sell any rivalry products. Maiyas gained immense popularity in snacks and RTE product categories in Bengaluru.

ITC- ITC, one of the major conglomerates in India had two categories of RTC foods- Aashirvaad offering a range of daily delights and Kitchen of India offering gourmet food of India.

\section{Why iD has real competition only from "home- made" batter?}

Answer:

Though a number of well-known brands were available during 2005-06 in for RTC and RTE food product categories, no organised player had entered the "readymade idli dosa" batter section in Bengaluru, the birth place of iD Fresh. A huge market was untapped and some local companies were serving the demand. Great opportunity for capturing the market was available to any company who could produce quality batter free from preservatives and customize to local taste and palate. In spite of a lot of hassles, India women used to prepare batter at home. iD followed the same recipe followed by them to keep the authentic taste. Musthafa always mentioned that if the Idli came out fluffy and soft, the credit should go to the lady who prepared it. iD aimed to complement her effort not to compete with her. Therefore, the challenge for the company was to make Indian women happy by supplying the authentic taste of the homemade batter.

\section{Prepare a SWOT analysis of the iD Fresh Food.}

A SWOT analysis of iD Fresh Food.

\begin{tabular}{|c|c|}
\hline $\begin{array}{l}\text { Strengths } \\
\text { 1. Pioneer at RTC-Idli-Dosa batter segment is } \\
\text { facing very little competition from large } \\
\text { organized companies. } \\
\text { 2. Brand trust was built among customers about } \\
\text { the taste and freshness of products which led to } \\
\text { returning loyal customers. } \\
\text { 3. USP (unique selling proposition) of iD fresh } \\
\text { food - its authentic recipe, using high quality } \\
\text { freshest ingredients and added no chemicals. } \\
\text { 4. Unique packaging and controlled delivery } \\
\text { chain helped the company to maintain consistent } \\
\text { quality and availability. Recently launched iD } \\
\text { Vada packet is highly appreciated and iD has } \\
\text { received a patent for it. } \\
\text { 5. Direct supply to retailers through the } \\
\text { company's own distribution vehicles and daily } \\
\text { replenishment model enabled iD to get better } \\
\text { control on distribution and maintain a good } \\
\text { relationship with retailers. } \\
\text { 6. A number of accolades in its hat like "Best } \\
\text { food marketing idea 2016", "Vocational } \\
\text { excellence award 2016", "Best packaging design } \\
\text { award 2015". }\end{array}$ & $\begin{array}{l}\text { Weakness } \\
\text { 1. USP poses a limitation to the company for } \\
\text { diversification of business. The company has a } \\
\text { limited option to add products in the fresh } \\
\text { products line categories. } \\
\text { 2.The shorter shelf life of products } \\
\text { 3. Centralised decision making- Close-knit } \\
\text { management styles, confined with mostly family } \\
\text { members. }\end{array}$ \\
\hline $\begin{array}{l}\text { Opportunities } \\
\text { 1. RTC packaged food segment in India is in the } \\
\text { nascent stage, huge market potential both in }\end{array}$ & $\begin{array}{l}\text { Challenges } \\
\text { 1. The biggest issue is to make the customers } \\
\text { believe that no preservatives are added to the }\end{array}$ \\
\hline
\end{tabular}


existing product range and new product range. iD is planning to enter all major cities of India.

2. Opportunity in the overseas market- Plan to enter the middle east market in Riyadh, Jeddah, and countries namely the USA, UK and Singapore targeting Indians staying there.

3. iD has established itself a reputed brand by consistent execution capabilities over the last 7 years, the same business model can be replicated for market penetration

4. Upgradation of the existing systeminnovation in packaging and automation in production units.

5. Forward Integration- iD is planning to start iD Café centre. packets as people often consider iD products as other unhealthy packed food items.

2. Correct estimation of demand and keep zero inventory level to reduce the wastage cost.

3. The clutter of local unorganised competitors who sell the product at a much lower rate.

4. Distribution, since refrigeration plays a big role in keeping the product fresh but with constant power cuts, power fluctuations, many times products are spoiled.

5. Changing lifestyle in Indian metrosPreference towards continental breakfast, especially among kids and young generation.

6. Entering the overseas market- Stringent food safety laws, maintaining the global standard, creating awareness in new geographies, infrastructure back up and effective distribution.

\title{
5. Should Mr. Musthafa, focus on product expansion with packaged food items of more shelf life to grab the current market opportunity?
}

\begin{abstract}
Answer:
iD is in the expansion mode, it may think of diversifying in other packaged food categories. But the company should consider its basic USP of serving preservative free natural food. It has gained the confidence of consumers by consistent quality, unique packaging and controlled delivery system. The company might explore some dry packaged food items, which are naturally having more shelf life. For wet packaged items, it should emphasize more on how to increase the shelf life of some of its products without adding chemicals but with innovative packaging. Research \& Development of the company should emphasize on innovative packaging.

6. As the company's USP is selling packaged food without preservatives, will it pose a threat of a very narrow product line? What are the other types of products the company should consider which will go along with its USP? Should the company diversify in other product lines?
\end{abstract}

\begin{abstract}
Answer:
With a narrow product line, the company should consider geographical expansion, market penetration and market development as its growth strategy. The USP poses a limitation to the company for diversification of business. iD has a limited option to add products in the fresh products line categories, which would go well with its existing business philosophy and therefore, very cautiously, the company should select its product ranges. Earlier, it had launched some products in different food product categories like appam batter, coconut chutney but they did not do well.

iD being a fast mover in RTC "idli dosa" segment was able a create an entry barrier in RTC market. It recently launched spill free packaging of "vada" batter, got the patent for it. This product gained instant popularity and helped the company penetrate further. It has entered in RTE parota (Indian bread) sections with wide array of parotas namely "Just heat whole wheat parota", "Just heat whole wheat chappati, "Just heat Malabar parota, "Just heat whole wheat parota junior", "Just heat mini parota." iD has a scope to add some more products like staffed parotas in this category. In dairy product section it has introduced "Paneer (cottage cheese) made by fresh lime juice and the product is yet to grow its market.
\end{abstract}


The company wanted to strengthen the super food portfolio by introducing batters made from healthy grains like ragi, millet, oats etc. In 2018, id launched sachet of coffee decoction and ready to fry vada batter. It is planning re-launch tomato and coconut chutney, which were failure earlier. the iD can diversify in other RTC and RTE packaged food categories, especially in dry packaged item section.

Students can suggest some other segments where the company can diversify and they should share their ideas to identify new product lines.

Suggested Reading

Chapter 12- Setting Product Strategy, Kotler, Keller, Koshy, Jha (2009), "Marketing Management- A South Asian Perspective”, $13^{\text {th }}$ Edition (Armstrong (2000), Pearson \& Prentice Hall-Page-307-330

Ansoff's “Strategies for Diversification” (1957).

7. After a certain period, is iD Fresh Food going to be another family run business with too muchcentralised decision making?

According to a Credit Suisse report, India has 108 publicly listed family-owned businesses. India ranked third highest after China and USA. (PTI, Times of India, Oct26, 2017). Tata, Birla, Ambani are some famous family owned big corporates in India. Of course, some of the family-run businesses find difficult to sustain once it grows. Graves \& Thomas (2006) indicated that the managerial capabilities of family firms lag behind those nonfamily counterparts, as they expand internationally. Another study by Banalieva and Eddleston (2011) claimed that family leaders are most beneficial when pursuing a regional strategy (i.e., high home-region focus (HRF)), whereas non-family leaders are more advantageous when pursing a global strategy. John L. Ward (1997) discussed the challenges to growth faced by Family owned business and mentioned best practices to overcome the challenges.

From various theories and existing literature, it is observed that there is no correct answer to the above question and it is controversial in nature. Some students may argue that iD would do well like other family-run Indian companies. They can bring appropriate logic and evidence to support their answers. Referring to Table 2 in Annexure students can argue that since iD has well-defined organisation structure and managed professionally, it might be able to achieve the projected growth.

Contrary other students might go for a debate stating the issues faced by family-run businesses while expanding internationally.

Theory:

Internationalization of Australian Family Businesses: a managerial capabilities perspective. (Chris Graves, Jill Thomas, 2006)

Home-region focus and performance of family firms: The role of family vs non-family leaders (Elitsa $R$ Banalieva and Kimberly A Eddleston, 2011)

John L. Ward (1997), “Growing the Family Business: Special Challenges and Best Practices” FAMILY BUSINESS REVIEW, vol. 10, no.4, December 1997 (C) Family Firm Institute, Inc.

\section{SUPPORTING STUDY MATERIALS}

\section{Theoretical Frameworks \& Models Discussed In Case}

\section{STP- Segmenting, Targeting and Positioning}

Effective marketing does not happen just like that- it needs a rigorous marketing plan. As marketing involves satisfying customers and delivers value to them, a detailed marketing plan has to be followed by any company to react to the changes in the environment, to face the competition in the market. The traditional view of marketing "one size fits all" does not work in today's competitive environment and a smart company should do homework 
on Strategic marketing which is all about "Segmenting, Targeting and Positioning (STP)". After completing the environmental analysis, a company should evaluate opportunities for increasing sales and profit using STP.

Segmentation- Market segment consists of a group of customers who share a similar set of need, wants, and responds to a firm's marketing effort in a similar way. The process by which a market is divided into different groups of customers with different needs wants and characteristics are called market segmentation. There are different methods of segmentation: geographic, demographic, psychographics, benefit and behavioural segmentation.

Targeting- Once the firm has identified its market segment opportunities, it should decide which market/markets to enter. The attractiveness of any segment depends on five criteria- measurable, substantial, accessible, differentiable and actionable. A firm should assess both the attractiveness of the target market (opportunities and threats based on SWOT analysis and the profitability of the segment) and its own competencies (Strength and weakness based on SWOT analysis). The target market is defined by a set of buyers sharing common needs or characteristics that the company decides to serve.

Positioning- The final step in market segmentation is positioning. Once a company decides its target market, it should also decide what positions it wants to occupy in that market. Positioning involves creating a particular image of the company and its product in consumers' mind compared to its competitors. Positioning is done by the way product is defined and implant its image by its unique benefit and differentiated features.

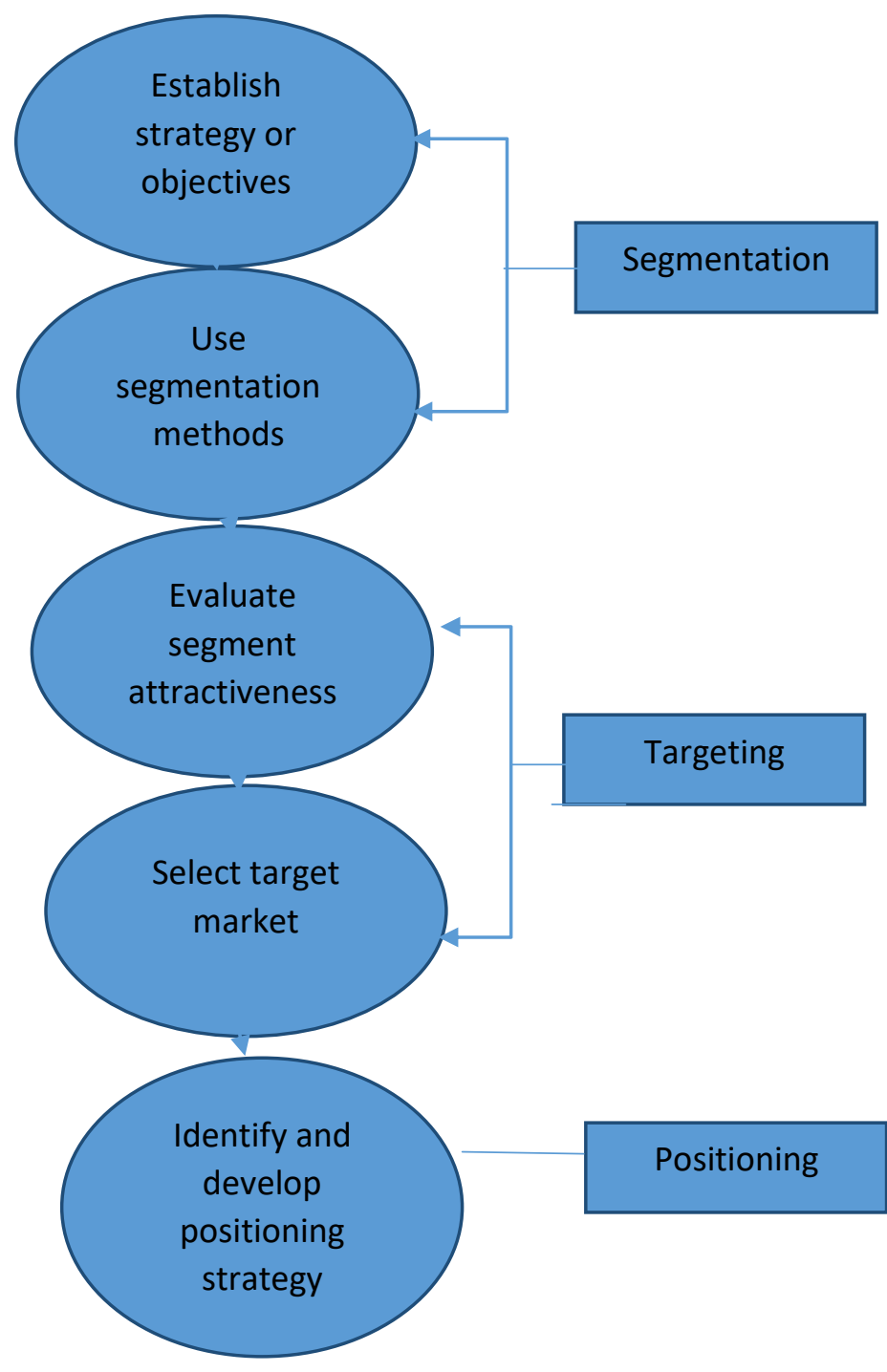

The Segmentation, Targeting and Positioning Process Source: Grewal / Levy- Marketing $\left(5^{\text {th }}\right.$ Edition $)$ - pp-269 
2. Marketing Mix: To achieve a market leader position, any organisation should be able to assemble all the marketing offers, called marketing mix. The marketing mix is all the marketing activities and integrated marketing programs to create, communicate and deliver value for consumers. Marketing activities come in all forms (Day, 1994).McCarthy classified all these marketing activities in four broad kinds, which he called as four Ps of marketing: Product, price, Place and promotion (McCarthy, Perreault, 2002).

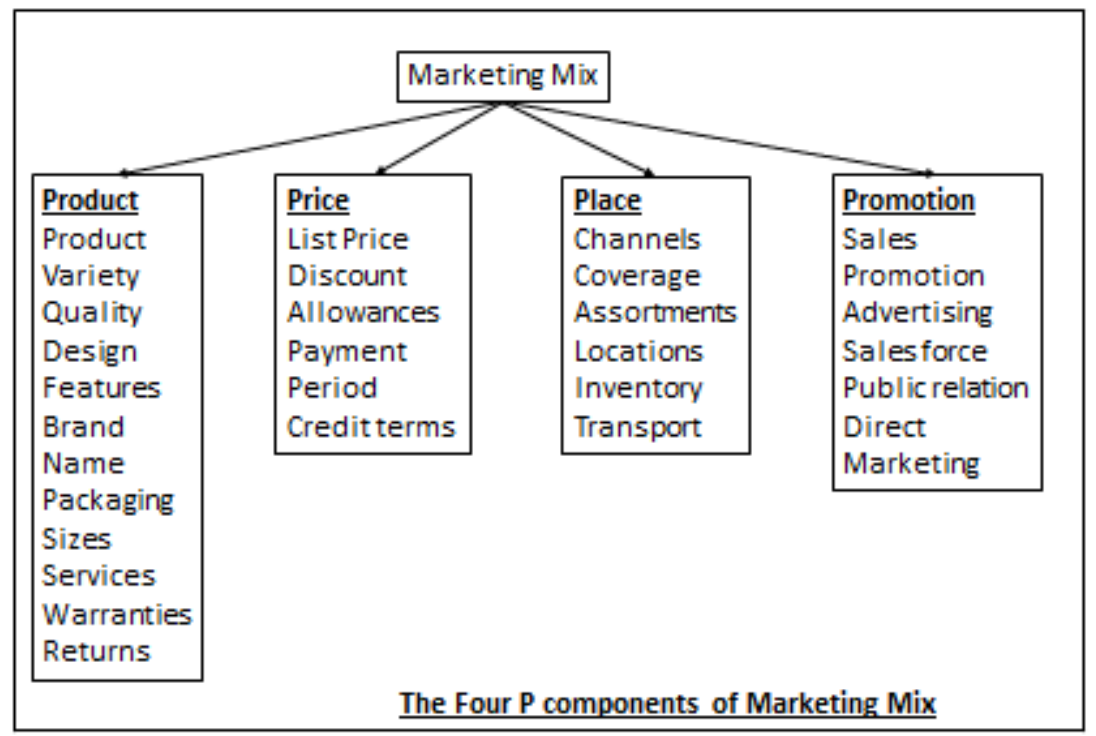

Source: Kotler, Keller, Koshy \& Jha - Marketing Management (13 ${ }^{\text {th }}$ Edition)

\section{Ansoff' Product-Market Matrix}

\section{Ansoff' product-market matrix}

\begin{tabular}{|l|l|l|}
\hline Product & Present & New \\
\hline Market & $\begin{array}{l}\text { Market } \\
\text { Penetration }\end{array}$ & $\begin{array}{l}\text { Product } \\
\text { development }\end{array}$ \\
\hline New & $\begin{array}{l}\text { Market } \\
\text { development }\end{array}$ & Diversification \\
\hline
\end{tabular}

Source: H I Ansoff,' "Strategies for Diversification”, Harvard Business Review, 1957, 5, pp-113-124

Strategic planners and marketers use Ansoff' Product-Market Matrix for finding out the growth directions for any organisation.

- Market penetration involves selling more products to the same market and a company attempts to intensify its presence in the existing market with its present product ranges. 
- Market Development involves selling the same products to new markets, either a company attracts more new users of existing products, or in new demographics or offering products in new geographies.

- Product Development involves selling new products in the existing market through the introduction of new products by concentrating more on product development.

- Diversification involves a substantial change in business definition either through customer function, customer groups and alternative technologies by the introduction of new product in a new market.

\section{SUGGESTED READING}

- Elitsa R Banalieva and Kimberly A Eddleston (2011), "Home-region focus and performance of family firms: The role of family vs non-family leaders", Journal of International Business Studies 42, 10601072

- E Jerome McCarthy and William D Perreault (2002), Basic Marketing: A Global-Managerial Approach, $14^{\text {th }}$ Edition (Homewood, IL: McGraw-Hill Irwin, 2002)

- Graves Chris, Thomas Jill (2006), "Internationalization of Australian Family Businesses: a managerial capabilities perspectives", Family Business Review, Volume: 19 issue: 3, page(s): 207-224

- Grewal /Levy (2017), "Marketing", $5^{\text {th }}$ Edition, Mc Graw Hill Education (India) Edition, Chapter 9268295

- Kotler, Keller, Koshy, Jha(2009), "Marketing Management- A South Asian Perspective", $13^{\text {th }}$ Edition (Armstrong (2000), Pearson \& Prentice Hall : Chapter 1- page-24-25, 34-35 Chapter 12, 13,14,15 $\& 16$.

- PTI, Times of India (2017), "India has third highest number of family-owned businesses: Report". Available at https://timesofindia.indiatimes.com/business/india-business/india-has-third-highestnumber-of-family-owned-businesses-report/articleshow/61244515.cms

- Saxena Rajan (2005), "Marketing Management", $4^{\text {th }}$ Edition, Tata McGrew-Hill, New Delhi, India. Chapter 1- page 27-28, Chapter 10-12, 13, 14, 15 \&19 